\title{
Cibercultura e evangelização
}

Orientador: Prof. Dr. Abimar Oliveira de Moraes

abimar@puc-rio.br

Pesquisador: Alexandre Magalhões Rangel

arangel@gmail.com

Projeto de Pesquisa: Questões atuais de Teologia Pastoral

Fonte: FAPERJ

Esta pesquisa tentou estabelecer relações entre a Cibercultura e a Evangelização. Numa sociedade da informação e da comunicação, a ação evangelizadora precisa ser repensada. Verificou-se se é possível uma pastoral ciberculturada, inserida nessa nova cultura amplamente dominada e administrada por jovens em busca de novas e criativas maneiras de se comunicar, para que a Boa Nova possa ser um anúncio vivificante também no ciberespaço. Não é o download por demanda, mas o brainstorming por colaboração coletiva que fará a diferença e construirá este novo espaço antropológico desterritorializado e fundado sobre as comunidades virtuais e as comunidades tribais. O retorno ao comunitário seja uma oportunidade ímpar para o coletivo Igreja, para o anúncio da Boa Nova e para a atividade missionária dos novos discípulos e discípulas numa pastoral ciberculturada. 